\title{
Lichen recolonisation in an urban-industrial area of southern Poland as a result of air quality improvement
}

\author{
Maja Lisowska
}

Received: 25 June 2010 / Accepted: 20 September 2010 / Published online: 9 October 2010

(C) The Author(s) 2010. This article is published with open access at Springerlink.com

\begin{abstract}
Dynamics of epiphytic lichen distribution and diversity in the town of Skawina, one of the major industrial centres of southern Poland, over the last 30 years, was documented in relation to air quality changes. Fieldwork was conducted in 2006-2007. A total of 34 species were recorded at 202 sites, which is similar to the historical data, however, significant qualitative changes occurred. Nitrogen- and dust-tolerant species have expanded and dominate, while some acidophytes, such as Lecanora conizaeoides, are in decline. Lichens have recolonised the former 'lichen desert' in the town centre. Species richness at study sites has increased; and an improvement in the health of lichen thalli was noted. These trends reflect air quality improvement, mainly $\mathrm{SO}_{2}$ decline in the last few decades and transport-related compounds, mainly $\mathrm{NO}_{x}$ and dust that have became the main pollutants. Host tree species and diameter diversity also contribute significantly to lichen species diversity in the study area. The recolonisation process seems far from complete and further changes in the lichen distribution and diversity in the study area are expected.
\end{abstract}

M. Lisowska $(\bowtie)$

Zdzisław Czeppe Department of Polar Research and

Documentation, Institute of Botany, Jagiellonian

University in Kraków, Kopernika 27,

31-501 Kraków, Poland

e-mail: maja.maslowska@uj.edu.pl
Keywords Lichens $\cdot \mathrm{SO}_{2} \cdot \mathrm{NO}_{x} \cdot$ Fluorine $\cdot$ Recolonisation $\cdot$ Air pollution

\section{Introduction}

Lichens are highly effective biomonitors of atmospheric pollution because of their morphological and physiological characteristics. They absorb water directly from the atmosphere through their thallus surfaces, together with different dissolved contaminants (Nimis et al. 2002). Despite their slow growth rates, some lichens rapidly respond to decreasing concentrations of air pollution, allowing even annual changes to be detected (Loppi et al. 2004). Since tree bark has a low buffering capacity in comparison with rock, soil or concrete (Hauck et al. 2008), epiphytic lichens are particularly sensitive to air pollution and are mainly used for monitoring.

Since Nylander's (1866) study in Paris, lichens have been used for both qualitative and quantitative determinations of air contaminants. Most of the studies have been focused on sulphur dioxide $\left(\mathrm{SO}_{2}\right)$ and nitrogen oxides $\left(\mathrm{NO}_{x}\right)$, but numerous other pollutants (e.g. fluorides, metals, phosphorus and radionuclides) have also been monitored using lichens (e.g. Gilbert 1971; Olech et al. 1981; Szymczyk et al. 1993; Conti and Cecchetti 2001). Nowadays, this kind of research may be used by environmental health services; e.g. mapping lichen diversity was employed to support a hypothesis 
about a correlation between air pollution and lung cancer (Cislaghi and Nimis 1997).

For many years, $\mathrm{SO}_{2}$ used to be the main pollutant, resulting in areas devoid of epiphytic lichens ('lichen deserts') in cities and industrial regions throughout much of the world (Purvis et al. 2003). The correlation between high concentrations of $\mathrm{SO}_{2}$ in the atmosphere and lichen decline is well documented (Seaward 1993), and also proved experimentally (Nash 1973). In last few decades, more severe policies on emission control led to significant declines of $\mathrm{SO}_{2}$ concentrations in most industrialised countries (Bates et al. 2001) resulting in the recolonisation of 'lichen deserts' and significant improvement in lichen diversity. It was demonstrated, for example, in European cities and conurbations, such as London (Rose and Hawksworth 1981), Paris (Seaward and LetrouitGalinou 1991), Rome (Munzi et al. 2007) and Torino (Isocrono et al. 2007) as well as smaller towns such as Siena and Pistoia in Italy (Loppi et al. 2002; Loppi and Corsini 2003). When $\mathrm{SO}_{2}$ levels are relatively low, other factors determine lichen growth in urban areas (e.g. Seaward 1997; Purvis et al. 2003).

The current study was carried out to complement the data about lichen dynamics in urban and industrial areas with results from the Central Europe. The town of Skawina (southern Poland) despite its small population $(24,000)$ is one of the major industrial centres in the Małopolska region, with a 500-MW coal-fired electric power station, an aluminium plant-one of the biggest producers of aluminium wire rod, aluminium wire and aluminium cable cores in Poland-and numerous other facilities (metallurgical industry, construction and food processing). Due to industrialisation in the 1960s and 1970s, the atmosphere of Skawina was heavily polluted, mainly with toxic dusts, fluorine compounds and $\mathrm{SO}_{2}$. These emissions affected plant, animal and human health in the whole region, including Kraków, and also had a negative effect on the conditions of the monuments in Kraków (Olech, personal communication). Studies on epiphytic lichens in the town conducted in the 1970s (Dudek 1974; Olech and Dudek 1981) showed a strong negative influence of the industrial emissions. Together with studies on lichen biota and diversity, fluoride concen- trations in lichens and mosses were analysed (Świeboda and Kalemba 1978; Olech et al. 1981). Publication of data documenting an extremely high degree of air pollution in Skawina contributed to the decision to reject an electrolysis process at the aluminium plant in 1981 (Szymczyk et al. 1993).

Since the 1980s, a major $\mathrm{SO}_{2}$ decline in the region occurred, together with changes in other air contaminants levels. Thus, significant changes in epiphytic lichen distribution and diversity in Skawina were expected to take place. The present study was aimed to document the actual state of air quality in the town and analyse changes since the 1974-1981 study (Olech and Dudek 1981), using distribution and diversity of epiphytic lichens as indicators of air pollution.

\section{Materials and methods}

\section{Study area}

Skawina, a town with a population of approximately 24,000 , is situated $15 \mathrm{~km}$ to the southwest of the centre of Kraków, southern Poland. The main industrial facilities of the town, a coalfired electric power station and an aluminium plant, are located in its western part. The mean annual rainfall, concentrated in summer, is about $680 \mathrm{~mm}$ and the mean annual temperature is $8.7^{\circ} \mathrm{C}$ (Matuszko 2007); the hottest month is July (mean temperature $18.9^{\circ} \mathrm{C}$ ) and the coldest is January $\left(-2.1^{\circ} \mathrm{C}\right)$. The prevailing winds are $\mathrm{SW}$ and $\mathrm{W}$. Since the town lies in the valley of the River Vistula, temperature inversions and fogs are frequent (German 2007).

Studies conducted in the early 1970s showed extremely high levels of $\mathrm{SO}_{2}$ and particular matter $\left(\mathrm{PM}_{10}\right)$ in the atmosphere of Skawina, with mean annual values of $100 \mu \mathrm{g} \mathrm{m}^{-3}$ and $200-500 \mu \mathrm{g} \mathrm{m}^{-3}$, respectively (Dudek 1974). Moreover, at that time the aluminium plant was emitting approximately $7 \times 10^{5} \mathrm{~kg}$ of hydrogen fluoride annually (Olech and Dudek 1981). However, since the 1980s, there has been a significant improvement in air quality following decreases of industrial emissions; a similar trend has been found for the whole Małopolska region (Fig. 1). Between 1987 and 1995, the level 


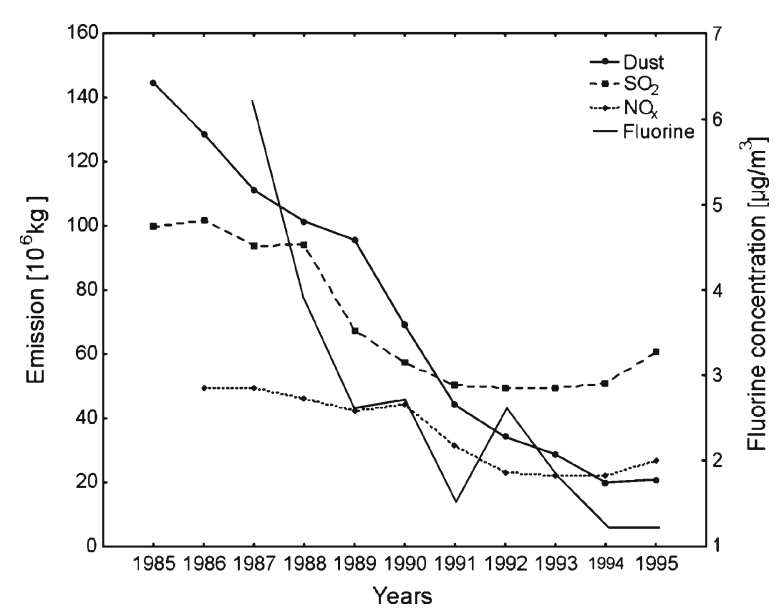

Fig. 1 Changes of dust, $\mathrm{SO}_{2}$ and $\mathrm{NO}_{x}$ emission levels in the former Kraków Voivoidship, 1985-1995, and changes in fluoride concentration in the atmosphere of Skawina between 1987 and 1995

of fluorine in the atmosphere of Skawina decreased sixfold (Fig. 1), and in comparison to the early 1970s (Dudek 1974), the average annual $\mathrm{SO}_{2}$ and $\mathrm{PM}_{10}$ concentrations are now approximately five and ten times lower, respectively (Fig. 2). Today, concentrations of these pollutants in Skawina do not, or only slightly, exceed standard levels (Fig. 3). Air quality data have been provided for Skawina and Małopolska from the air monitoring network in the Małopolska region (Małopolska

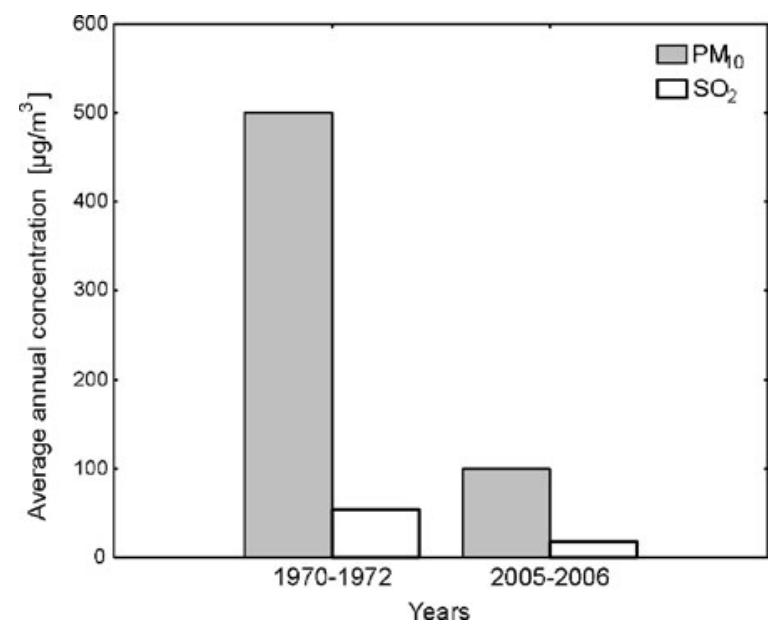

Fig. 2 Changes of $\mathrm{SO}_{2}$ and dust $\left(\mathrm{PM}_{10}\right)$ annual average concentrations in the atmosphere of Skawina between 1970s and present

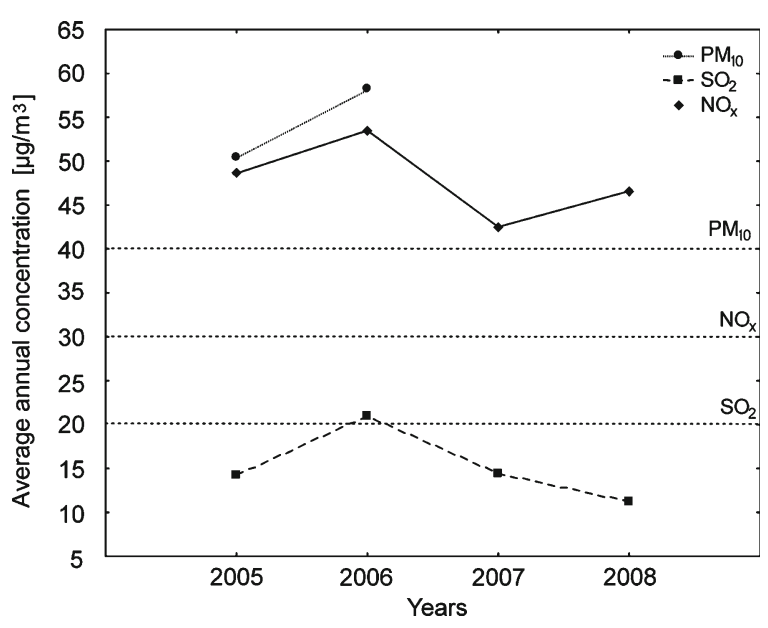

Fig. 3 Average annual concentration of dust $\left(\mathrm{PM}_{10}\right), \mathrm{SO}_{2}$ and $\mathrm{NO}_{x}$ in the atmosphere of Skawina, 2005-2008. Standard levels $\left[\mu \mathrm{g} \mathrm{m}^{-3}\right], \mathrm{PM}_{10}-40, \mathrm{SO}_{2}-20, \mathrm{NO}_{x}-30$

Sieć Monitoringu Powietrza 2007) and reports by the Voivoidship Inspectorate for Environmental Protection in Kraków (Wojewódzki Inspektorat Ochrony Środowiska w Krakowie 1994-2005).

\section{Field studies}

Field studies were conducted in 2006-2007. The study area and distribution of study sites were established according to the maps by Olech and Dudek (1981) within the 1970s administrative boundaries of Skawina. A total of 202 study sites were selected (Fig. 4). Deciduous trees with the highest number of lichen species were chosen at each study site, one tree or rarely a group of two to three trees, following the methods adopted by Olech and Dudek (1981) to provide as accurate comparison of the results as possible. Tree trunks were investigated from their bases to about $170 \mathrm{~cm}$ from the ground. Lichen species present and their cover (estimated by eye as a percentage of the investigated surface) were recorded, together with general information about each site (locality, tree species and trunk girth). Samples for further taxonomic identification were collected when necessary. Anecdotal information about any abnormalities of morphology of thalli (colour, shape; small but healthy thalli without soralia or apothecia were considered as young) was also gathered. 


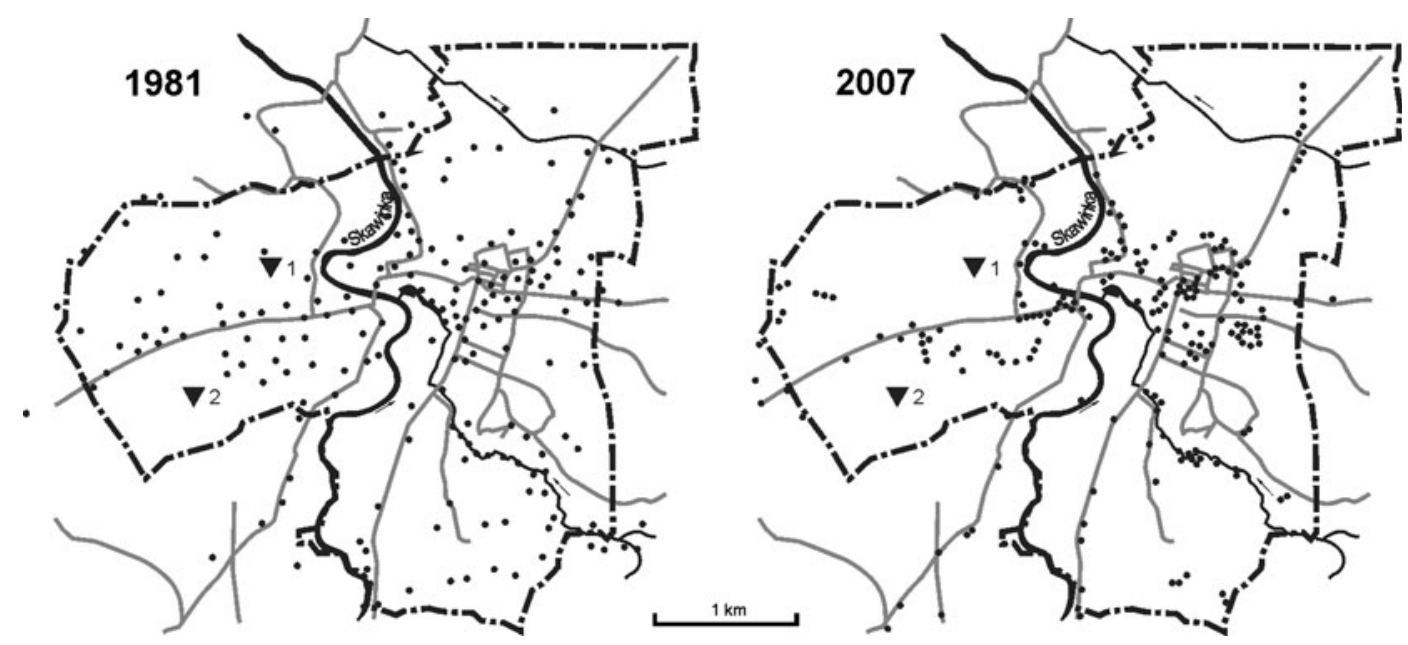

Fig. 4 Boundaries of Skawina from the 1970s and distribution of study sites in the 1970s (after Olech and Dudek 1981) and in 2007. 1 Aluminium plant, 2 power plant

Analysis methods

A list of epiphytic lichen species identified, their abundance and distribution for the present study was compared with corresponding data from that of Olech and Dudek (1981). Since it was not possible to relocate the exact trees from the previous study in each study site, an additional analysis was performed to test the possible effect of the phorophyte diversity on lichen species richness. Two sample proportion $Z$ tests were employed to analyse the differences in the abundance of each lichen species and phorophytes as well, as changes in occurrence of acidophilic and nitrophilic lichen taxa. The change in the average number of species in one site was tested using the independent two samples Student's $t$ test. Analyses of variance were performed to test the effects of tree species diversity and tree diameter on lichen diversity. The statistical analyses were performed using STATISTICA software (version 9.0) (StatSoft, Inc. 2009).

Comparative maps of lichen bioindication zones for the two sampling periods were constructed according to the qualitative scale of Kiszka (1992). The scale is a modified version of an 11-grade scale (0-10) of Hawksworth and Rose (1970), correlating the presence or absence of certain epiphytic lichen species (indicator species) with $\mathrm{SO}_{2}$ concentrations in the air, made to suit Polish lichen biota composition. To obtain more legible pictures, some grades were merged on the maps. An area devoid of epiphytic lichens ('lichen desert'), where only green algae occurred on tree trunks, was classified as zone I ( 0 and 1 grade in Hawksworth and Rose's scale); zone II (2 and 3 grade) was characterised by the presence of crustose lichens such as Lecanora conizaeoides, Scoliciosporum chlorococcum and Amandinea punctata, and only one foliose species, Physcia adscendens; zone III (4 grade) supported foliose species, such as Phaeophyscia orbicularis, Xanthoria parietina, Hypogymnia physodes, Parmelia sulcata and Physconia grisea.

The nomenclature followed Fałtynowicz (2003) and was updated according to the Index Fungorum (http://www.indexfungorum.org, 2010), and in the case of Lecanora dispersa and Lecanora semipallida according to Śliwa (2007); aggregate names have been applied for Lecanora saligna and Lepraria incana. The species names used in the studies by Dudek (1974) and Olech and Dudek (1981) were updated according to the Index Fungorum (http://www.indexfungorum.org, 2010). Discrimination between acidophilic and nitrophilic species followed Smith et al. (2009), also three other publications (van Herk 1999; Seaward and Coppins 2004; Davies et al. 2007) were taken into account. 


\section{Results}

A total of 34 epiphytic lichen species were recorded at 202 sites. The overall number of species has not significantly changed since the previous studies (Olech and Dudek 1981), when 35 species in 220 sites were found, but there have been qualitative changes (Table 1). Nine species
Table 1 List of epiphytic lichen species noted in Skawina in the 1970s (Olech and Dudek 1981) and in 2007, their tolerance to nutrients (after Smith et al. 2009) and frequency ( $\%$ of sites)
Species recorded in 2007 only are marked with (*). Species which have significantly changed their frequency are in bold font $a$ acidophilic, $d$ dust tolerant, $n$ nitrophilic ${ }^{a}$ Lecanora saligna counted together with the former Lecanora sarcopis (Wahlb.) Rohl

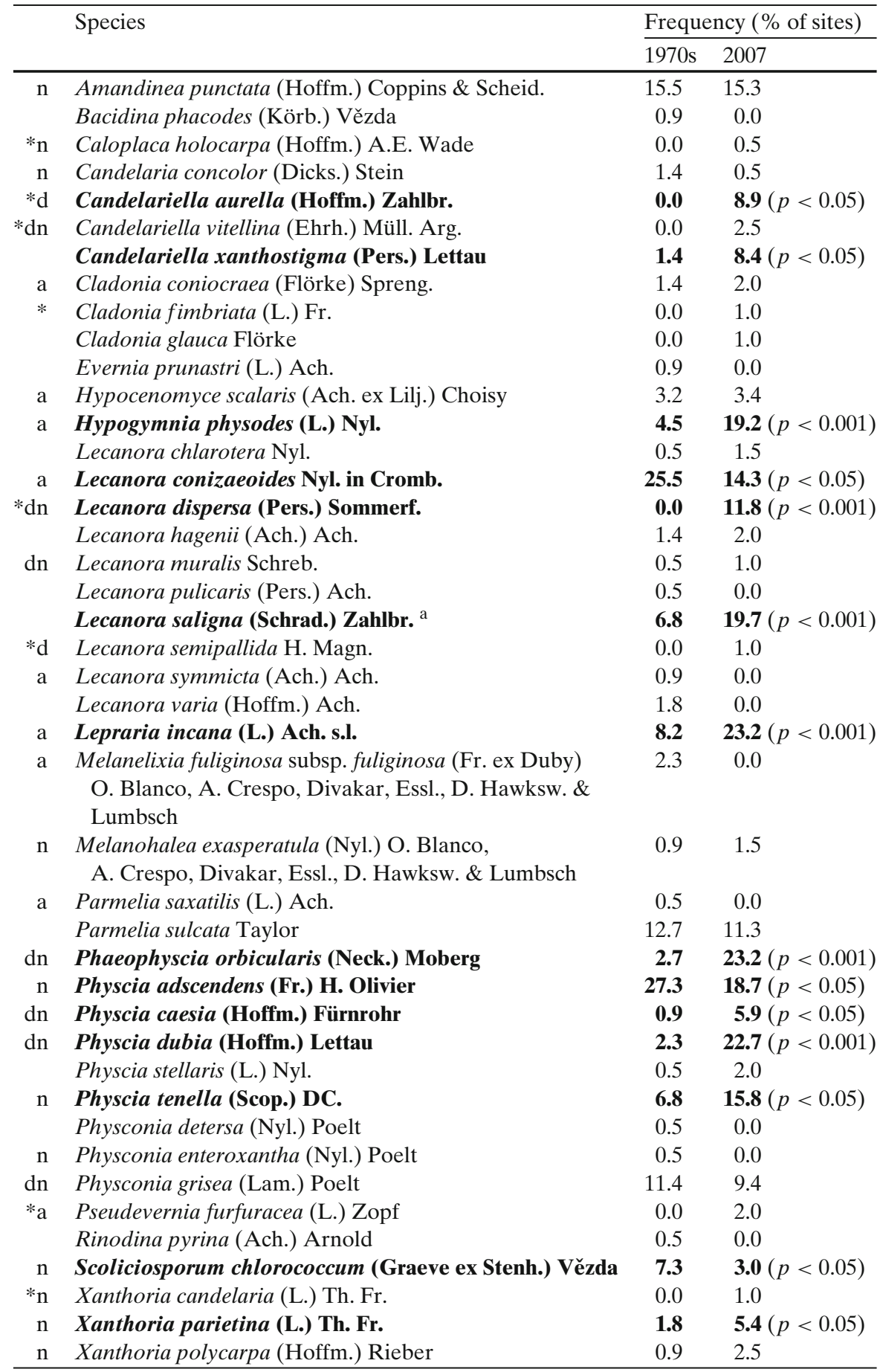




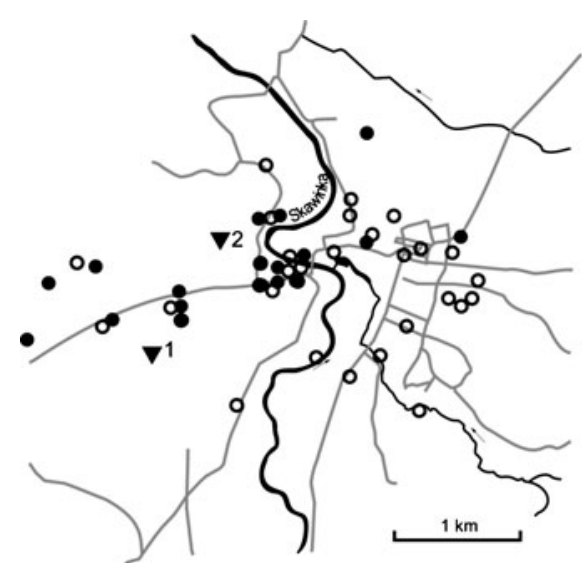

Fig. 5 Distribution of Candelariella aurella (full circles) and Lecanora dispersa (hollow circles) in Skawina in 2007. 1 Aluminium plant, 2 power plant

new to Skawina were recorded (Caloplaca holocarpa, Candelariella aurella, Candelariella vitellina, Cladonia fimbriata, Cladonia glauca, $L$. dispersa, L. semipallida, Pseudevernia furfuracea and Xanthoria candelaria), most of which occurred in the western part of the town and in suburban areas; C. aurella, C. vitellina and $P$. furfuracea were also present in the centre of the town. Ten species which were not found during the present study but had been recorded previously (Olech and Dudek 1981) from a few sites were Bacidina phacodes, Evernia prunastri, Lecanora pulicaris, Lecanora symmicta, Lecanora varia, Melanelixia fuliginosa, Parmelia saxatilis, Physconia detersa, Physconia enteroxantha and Rinodina pyrina. A few species (C. aurella (Fig. 5), C. vitellina, L. dispersa (Fig. 5), L. semipallida, Physcia caesia (Fig. 6) and Lecanora muralis) usually reported in Poland from rocks and concrete (Fałtynowicz 2003), were found on tree trunks, mainly in the western part and the centre of the town; C. aurella mainly occurred near the former aluminium plant and the power station. The two Candelariella species and the two Lecanora species are new to the epiphytic lichen biota of the town, while $P$. caesia and $L$. muralis were present on tree trunks during the previous survey. Two of the recorded species, Melanohalea exasperatula and $P$. furfuracea, are legally protected in Poland (Rozporządzenie Ministra Środowiska 2004).

In 1981, the most abundant species were $P$. adscendens and L. conizaeoides, being noted in more than $20 \%$ of the studied sites (Table 1 ). Only three other species, A. punctata, $P$. sulcata and $P$. grisea, were found in more than $10 \%$ of these sites. During the current study, significant $(p<0.05)$ decreases in number of occurrences of both $L$. conizaeoides and $P$. adscendens observed (Table 1, Fig. 6), together with a shrinkage in their urban distribution. P. orbicularis, L. incana s.l. and Physcia dubia proved to be the commonest species in the studied area, now occurring in more than $20 \%$ of all sites and showing the greatest increase $(p<0.001)$ in the number of localities (Table 1, Fig. 6). H. physodes (Fig. 6) and $L$. saligna, now present in almost $20 \%$ of sites, were previously noted in less than $5 \%$ and $7 \%$ of sites, respectively, and a significant increase $(p<0.05)$ was also observed in the number of localities of Candellariella xanthostigma, P. caesia (Fig. 6), Physcia tenella and $X$. parietina. The distribution of H. physodes (Fig. 6) and P. tenella has extended not only close to the borders of the town, but also in the centre. Only young specimens of these two species were found in 14 out of 39 and seven out of 32 sites, respectively.

A significant $(p<0.001)$ increase in epiphytic lichen diversity (measured as the number of species at a site) has occurred, the average rising from $1.55 \pm 2.05$ to $2.81 \pm 1.74$. In 1981, almost half of investigated trees (101 out of 220) were devoid of lichens (Olech and Dudek 1981). Currently, although sites with a low number of lichen species were the most frequent (Fig. 7), only two sites were totally devoid of lichens; furthermore, the proportion of sites with six and more species has increased from $4.5 \%$ to $8 \%$, which is also statistically significant $(p<0.001)$. Analysis of variance showed that both tree species and tree diameter diversity contributed to the lichen diversity during the current study ( $\mathrm{df}=17$ and $F=3.15 ; \mathrm{df}=50$ and $F=1.97$, respectively; $p<$ $0.001)$.

In 1981, willows (Salix spp.) proved to support the highest number of different lichen species (overall 26 spp.) and were the most numerous genus of trees bearing any lichen (Table 2). Currently, although their part in the study was significantly smaller than in $1981(p<0.001)$, no significant change occurred in the number of lichen species supported (Table 2). Other frequent trees 
Fig. 6 Distribution of selected epiphytic lichen species in Skawina in the 1970s (after Olech and Dudek 1981) and 2007. 1 Aluminium plant, 2 power plant
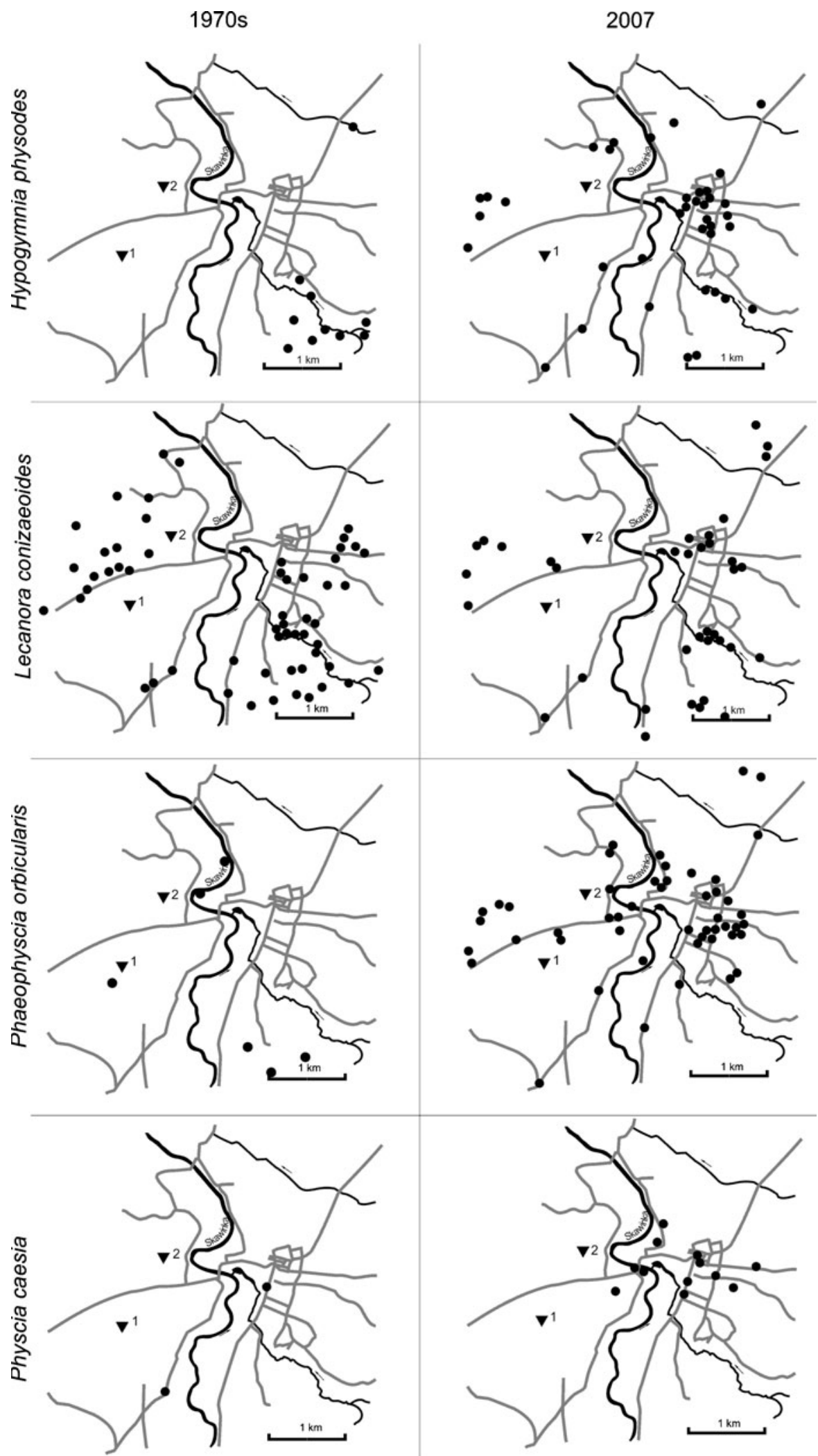


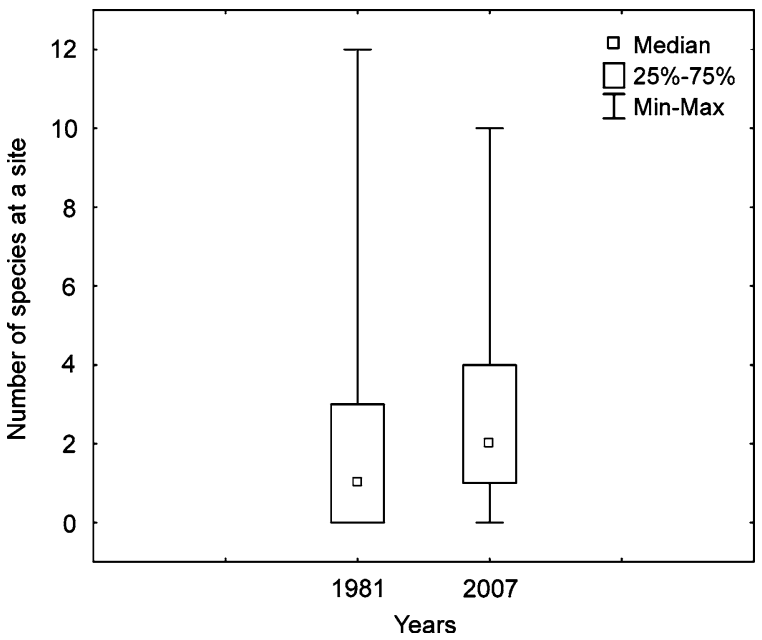

Fig. 7 Percentage of study sites with different number of species in the 1970s (Olech and Dudek 1981) and 2007

during the previous studies, Betula pendula, Alnus glutinosa and Tilia cordata showed no significant differences in either their number or number of lichen species supported (Table 2).

The most significant $(p<0.001)$ increases occurred in the number of poplars (Populus spp.) in the study sites and also in the number of lichens found on them. During the current studies poplars, mainly Populus nigra var. italica, were approximately one third (overall 68) of all studied trees and supported the highest number of lichen species (overall 26 spp.). Quercus robur and Acer pseudoplatanus were also significantly more numerous and supported more lichen species (Table 2).

Lichen cover was higher than in the previous survey when, according to Dudek (1974), coverage of most tree trunks was up to $10 \%$ and only in one site did cover achieve 20-30\%. Currently, almost one quarter of the sites had $30 \%$ cover, and in some cases the trunks were almost entirely covered by lichens (up to $90 \%$; Fig. 8 ).

Almost all specimens collected during the previous studies (Dudek 1974; Olech and Dudek 1981) were to some degree damaged, with deformation and underdevelopment of thalli or unable to produce spores. Thalli often had discoloured, necrotic fragments, and injuries were visible not only on foliose thalli of species such as $P$. sulcata or $H$. physodes, but even on crustose thalli of
Table 2 List of host trees, their number in the 1970s (Olech and Dudek 1981) and in 2007 and number of lichen species supported
Statistically significant changes are written in bold

$* p<0.001 ; * * p<0.05$

\begin{tabular}{|c|c|c|c|c|}
\hline \multirow[t]{2}{*}{ Tree species } & \multicolumn{2}{|c|}{ Number of sites } & \multicolumn{2}{|c|}{$\begin{array}{l}\text { Total of lichen species supported } \\
\text { by a tree species }\end{array}$} \\
\hline & $1970 \mathrm{~s}$ & 2007 & $1970 \mathrm{~s}$ & 2007 \\
\hline Acer negundo & 0 & 2 & 0 & 6 \\
\hline Acer platanoides & 0 & 1 & 0 & 1 \\
\hline Acer pseudoplatanus & $\mathbf{0}$ & $12^{* *}$ & $\mathbf{0}$ & $16^{*}$ \\
\hline Aesculus hippocastanum & 1 & 2 & 1 & 1 \\
\hline Alnus glutinosa & 9 & 7 & 10 & 5 \\
\hline Betula pendula & 12 & 27 & 11 & 17 \\
\hline Crataegus monogyna & 0 & 1 & 0 & 1 \\
\hline Fagus silvatica & 2 & 0 & 3 & 0 \\
\hline Fraxinus excelsior & 1 & 10 & 1 & 12 \\
\hline Malus domestica & 2 & 0 & 4 & 0 \\
\hline Morus nigra & 3 & 0 & 4 & 0 \\
\hline Pinus silvestris & 8 & $\mathbf{0}^{* *}$ & 4 & $\mathbf{0}$ \\
\hline Populus sp. & 9 & $68^{*}$ & 6 & $26^{*}$ \\
\hline Prunus avium & 1 & 0 & 1 & 0 \\
\hline Prunus domestica & 2 & 0 & 3 & 0 \\
\hline Quercus robur & 5 & $22 * *$ & 7 & $14 * *$ \\
\hline Robinia pseudoacatia & 1 & 0 & 1 & 0 \\
\hline Salix sp. & 55 & $30 *$ & 26 & 20 \\
\hline Sorbus aria & 0 & 1 & 0 & 1 \\
\hline Sorbus aucuparia & 2 & 0 & 1 & 0 \\
\hline Tilia cordata & 11 & 14 & 9 & 15 \\
\hline Ulmus sp. & 0 & 2 & 0 & 2 \\
\hline
\end{tabular}




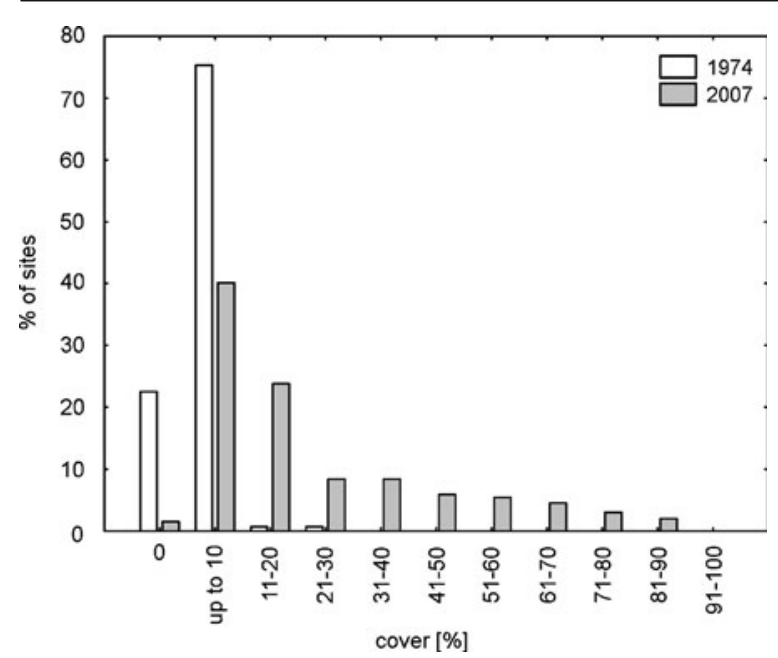

Fig. 8 Percentage of study sites with different lichen cover values in 1974 (Dudek 1974) and 2007

L. conizaeoides. Healthy specimens were found only in the northern and southern boundaries of the town (Dudek 1974). During the present study, improvement of the condition of thalli was observed. Specimens with discoloured thalli were found mainly on the main streets in the centre of the town, and west of the power station and aluminium plant.

A change is visible when comparing maps of lichen bioindication zones for 1981 and 2007. The 'lichen desert' (zone I), which was previously spread from SW to NE across the town, has practically disappeared and is now reduced to isolated sites, mainly in the town centre (Fig. 9). Much of the former 'lichen desert' is now classified as zone II, with characteristic crustose species L. conizaeoides, L. saligna, S. chlorococcum, A. punctata, L. incana s.l. and the foliose P. adscendens now present. Most of the species now found in areas formerly devoid of lichens were previously present in the suburban areas and four species new in Skawina, $C$. aurella, $C$. vitellina, $P$. furfuracea and $X$. candelaria, were also recorded there. Zone III, with characteristic foliose species (P. orbicularis, X. parietina, H. physodes, P. sulcata and $P$. grisea), now covers most of the study area, including fragments of the former 'lichen desert'. Single sites classified as zone IV, with characteristic species Physcia stellaris, M. exasper-

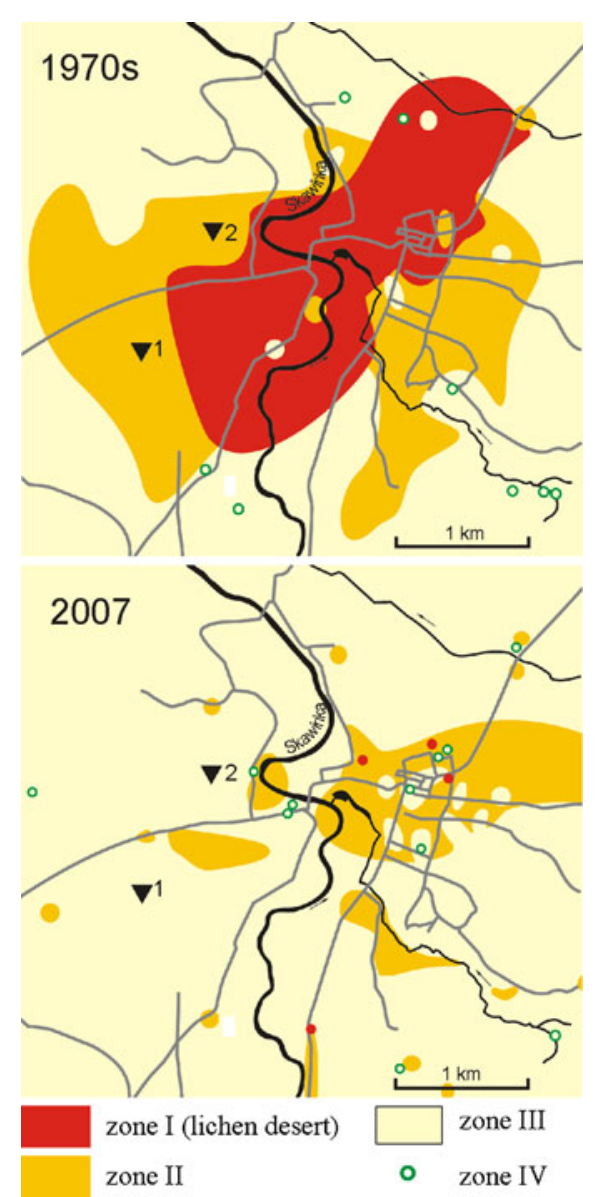

Fig. 9 Comparison of lichen bioindication zones in Skawina between the 1970s (after Olech and Dudek 1981) and 2007. 1 Aluminium plant, 2 power plant

atula and Candelaria concolor, were found, even in the city centre and the former 'lichen desert'.

\section{Discussion}

Major changes in epiphytic lichen biota composition, distribution and diversity were observed in the study area (Table 1). About one-quarter of taxa (nine species) are new to Skawina, including species associated with nutrient-rich or dustcontaminated substrata (C. aurella, C. vitellina, $L$. dispersa and L. semipallida) which have colonised trees adjacent to main roads and industrial plants (Fig. 5). These species may have been present in the study area in the past, but limited to rocks and concrete, because similar trends occurred in other 
areas, e.g. in London (Davies et al. 2007). As $L$. dispersa was also recorded on trees in nitrogenpolluted areas of London (Davies et al. 2007), it seems that this species and possibly other epilithic lichens with similar ecological preferences may become frequent on tree bark in urban and industrial areas.

Some species not found during the present study had been recorded previously in a very few sites (Table 1). There are numerous possible causes of these losses, including inability to survive, felling of their phorophytes or being missed during the recent field studies.

The proportion of both acidophilic and nitrophilic species did not significantly changed between the 1970s and 2007. However, the current most frequent lichens (Table 1) are nitrogen and dust tolerant (e.g. van Herk 1999; Seaward and Coppins 2004; Davies et al. 2007). On the other hand, significant increases in the frequency of $H$. physodes (Fig. 6), considered as an acidophilic species (van Dobben et al. 2001) and also $L$. incana s.1. (Bates et al. 2001), were frequently observed; L. incana s.l., despite preferring low substratum $\mathrm{pH}$, seems to be quite tolerant to $\mathrm{NO}_{x}$ (Davies et al. 2007), which might explain its high frequency in the study area. However, $H$. physodes seems to show the opposite trend elsewhere; Bates et al. (2001), for example, reported that although in SE England it is the commonest macrolichen on $Q$. robur, it has shown a significant decline with falling $\mathrm{SO}_{2}$ levels, as is the case in London (Davies et al. 2007).

The ecological preferences of lichen species and bark $\mathrm{pH}$ of the phorophytes seem to be well linked in the study area. Nitrophilic lichens, such as $P$. orbicularis, Physcia spp. and $X$. parietina were found most often on poplars (Populus spp.) and willows (Salix spp.). Acidophilic H. physodes, $L$. conizaeoides and $L$. incana preferred trees with acid barks: $Q$. robur and B. pendula; however, they were also frequently noted on Salix spp. Therefore, it is likely that substrate eutrophication, which must have followed falling $\mathrm{SO}_{2}$ level, is not the main factor determining the occurrence of nitrophytes.

Other European authors also report the dominance of nitrophilic lichens in urban areas. In Torino, Italy $P$. orbicularis and $P$. adscendens, present in over $80 \%$ of the sampling stations, are the commonest species, and nitrophilic species in general contribute significantly to lichen diversity (Isocrono et al. 2007). On the other hand, in Rome (Munzi et al. 2007), epiphytic lichen species recorded are known to prefer acid and sub-acid bark and are strongly influenced by the proximity of the sea.

The strongly acidophilic L. conizaeoides shows a significant decline both in frequency and extent and seems to be disappearing from suburban areas (Fig. 6). This lichen often grows in places where high $\mathrm{SO}_{2}$ concentration restricts the occurrence of other species. There are several possible explanations for this. According to the most recent research (Hauck et al. 2008) $\mathrm{SO}_{2}$ tolerance in lichens is strongly correlated with hydrophobicity of the thallus surface, so the success of $L$. conizaeoides in $\mathrm{SO}_{2}$-polluted areas can now be attributed to the hydrophobicity of its surface and also to its high dispersal ability. On the other hand, loss of L conizaeoides with declining $\mathrm{SO}_{2}$ concentrations over more than 20 years reported from SE England by Bates et al. (2001) is explained by the fact that $L$. conizaeoides requires elevated $\mathrm{SO}_{2}$ inputs (or some closely related chemical factor) for healthy growth. The authors also suggest that competitive interactions with other epiphytes and attacks by the parasitic fungus Athelia arachnoidea may play an important role. This may be the case in Skawina as well, since many fungusinfected specimens were observed.

In the Małopolska Voivoidship, where Skawina is situated, the number of vehicles is steadily growing. In 2000-2007, the number of registered passenger cars increased by approximately $49 \%$ from 829,000 to 1,234,000 (Urzad Statystyczny w Krakowie 2008). This trend may be one of the major factors limiting lichen growth and diversity in the study area, as well as for the whole region. $\mathrm{NO}_{x}$ is rapidly dispersed away from roads, decreasing by about $70 \%$ within $20-30 \mathrm{~m}$ of the roadside (Davies et al. 2007). Thus its dispersion and influence will differ considerably within the study area and may contribute to lichen diversity. Numerous studies have shown that when the $\mathrm{SO}_{2}$ level in the atmosphere is relatively low and no longer the main factor affecting lichen vegetation (e.g. Loppi et al. 2004), transport-related $\mathrm{NO}_{x}$ 
plays a major role in determining lichen distribution and diversity in urban areas. In Montecatini Terme (Central Italy), vehicular traffic was concluded to be the main source of atmospheric pollution (Loppi et al. 2004). In Pistoia, Central Italy (Loppi and Corsini 2003), lichen colonisation is determined by declining $\mathrm{SO}_{2}$ concentrations, while major injuries to lichen communities are caused by the constantly high levels of $\mathrm{NO}_{x}$. Purvis et al. (2003) provide evidence for the impact on lichen growth during episodic high exhaust emissions coupled with unusual climatic conditions in London. Results of research carried out in Siena (Loppi et al. 2002) show that the combined effects of $\mathrm{SO}_{2}$ and $\mathrm{NO}_{x}$, which are observed when concentrations are below, or at the threshold for, individual injury response (Balaguer et al. 1997), can be expected. Frati et al. (2006) on the other hand showed no association between $\mathrm{NO}_{2}$ concentrations and the diversity of epiphytic lichens in the vicinity of a busy road in Central Italy, probably because of the low $\mathrm{NO}_{2}$ values measured.

The increase in lichen species richness in Skawina is in agreement with numerous studies, (e.g. Seaward 1997; Loppi et al. 2004). Increases in lichen diversity (measured with different methods) have also been recorded in, for example, Siena (Loppi et al. 2002) and Pistoia (Loppi and Corsini 2003). Although air quality is the main factor determining lichen diversity in the study area, ecological conditions, also contribute to species richness. During the current studies sites with the highest number of species were single standing trees, mostly poplars (Populus spp.) and willows (Salix spp.), located in the vicinity of water.

Bark $\mathrm{pH}$ also is a factor of significant importance for occurrence of epiphytic lichens. It is known to influence sulphur speciation, which determines its toxicity (Gilbert 1968) and may influence speciation of other potentially toxic elements (Larsen et al. 2007). Generally, acidophytes are connected with bark pH (Davies et al. 2007). Diversity of phorophytes leads to a higher epiphytic lichen species richness, caused not only by the differences in the bark $\mathrm{pH}$ between tree species, but also by different bark texture. The contribution of tree species diversity to the lichen diversity during the current study, confirmed by statistical analysis has to be taken into account when interpreting the results. Also the variation in tree diameter plays an important role, as within one tree species bark texture changes with age and thus can support different lichens. Moreover, the older the tree, the higher probability of being colonised by lichens.

The selection of study sites was not totally random and this can influence the results. During the previous study (Olech and Dudek 1981), an attempt was made both to cover equally all the study area and to find the trees supporting the highest number of lichen species. Thus, the same method was applied during the current study. The differences in study sites localisation may be caused by changes in the distribution of trees between the sampling periods and also by difficult access to vast areas of industrial zones.

The lichen desert in Skawina is no longer present as a compact area (Fig. 9). As predicted, the area with the most impoverished lichen biota spreads across the city centre, NE from the main industrial facilities, according to the prevailing winds, as visible in other cities, such as Košice (Bačkor et al. 2003) and Rome (Munzi et al. 2007). A decline in the area devoid of epiphytic lichens has also been also reported from those cities where comparisons with historical data were possible, such as London (Rose and Hawksworth 1981), Rome (Munzi et al. 2007) and Torino (Isocrono et al. 2007); the authors agree that $\mathrm{SO}_{2}$ decline is responsible for this trend. In Pistoia (Central Italy), although the general situation has improved, the lichen desert still exists; this is explained by the constantly high levels of $\mathrm{NO}_{x}$ (Loppi and Corsini 2003).

The bioindication zones in Skawina are currently not clearly defined (Fig. 9); this, as well as young specimens (mainly of $H$. physodes and $P$. tenella) found during the fieldwork, suggests that the recolonisation process is far from complete. It can also illustrate the difficulties in using the Hawksworth and Rose's (1970) scale in areas where $\mathrm{SO}_{2}$ level is relatively low. The scale was calibrated under high $\mathrm{SO}_{2}$ concentration and no longer gives a clear picture when $\mathrm{SO}_{2}$ has decreased and other substances have become more important. This drawback of the method was noticed in England (Hawksworth 2002) as soon as 
the air quality in studied areas had increased. In case of further lichen monitoring in Skawina other methods have to be employed.

The presence of the sites classified as zone IV in the vicinity of the sites devoid of lichens cannot be explained either by microclimatic conditions, as zone IV sites are scattered on all the study area, or by difference in diameter, since it proved statistically insignificant. Difference in tree species may partially explain this state. Most of the trees bearing zone IV lichen species were poplars (Populus spp.) and this tree species often supports a relatively high variety of lichens. The occurrence of single trees devoid of lichens in a large area with well-preserved epiphytic lichen vegetation may also be random and caused by other, here unimportant factors.

It has been shown that air quality maps constructed with the method of Hawksworth and Rose (1970) and the IAP (e.g. Le Blanc and De Sloover 1970) give similar results (Gombert et al. 2004). However, statistical comparison of the data from Skawina with other results may cause problems due to the different methods employed. Where lichen cover is concerned, since no standardised method was employed to estimate this by Olech and Dudek (1981) and no data about the girth of trunks were collected, comparisons show only general tendencies. Sampling and analyses adjustment to those of Olech and Dudek (1981) were nevertheless necessary where possible for credible comparisons. Despite these problems, the data still demonstrated the significance of changes which have occurred during the last few decades.

\section{Conclusions}

Compared with historical data, several major changes in epiphytic lichen vegetation in Skawina are clearly visible. Nitrogen- and dust-tolerant species dominate, while some acidophytes, such as L. conizaeoides, are in decline. The 'lichen desert' in the centre has almost disappeared, and species diversity of study sites has increased. The health of lichen thalli has improved and many young specimens were recorded. Lichen recolonisation reflects the improvement in air quality, mainly the decline in $\mathrm{SO}_{2}$. Transport-related $\mathrm{NO}_{x}$ together with substrate eutrophication determine lichen diversity and distribution in the study area, but nonenvironmental factors, such as tree species and diameter, also proved important. The recolonisation process is far from complete; therefore further changes are expected in the coming years.

Acknowledgements I wish to thank Professor Maria Olech for supervising my work, patience and many guidelines throughout the writing process, Lucyna Śliwa, Ph. D. for revision of the L. dispersa group and Professor Mark Seaward for correction of the English manuscript and useful remarks. I also thank the anonymous reviewers for constructive comments.

Open Access This article is distributed under the terms of the Creative Commons Attribution Noncommercial License which permits any noncommercial use, distribution, and reproduction in any medium, provided the original author(s) and source are credited.

\section{References}

Bačkor, M., Paulíková, K., Geralská, A., \& Davidson, R. (2003). Monitoring of air pollution in Košice (Eastern Slovakia) using lichens. Polish Journal of Environmental Studies, 2, 141-150.

Balaguer, L., Manrique, E., \& Ascaso, C. (1997). Predictability of the combined effects of sulphur dioxide and nitrate on the green-algal lichen Ramalina farinacea. Canadian Journal of Botany, 75, 1836-1842.

Bates, J. W., Bell, N. J. B., \& Massara, A. C. (2001). Loss of Lecanora conizaeoides and other fluctuations of epiphytes on an oak in S.E. England over 21 years with declining $\mathrm{SO}_{2}$ concentrations. Atmospheric Environment, 35, 2557-2568.

Cislaghi, C., \& Nimis, P. L. (1997). Lichens, air pollution and lung cancer. Nature, 387, 463-464.

Conti, M. E., \& Cecchetti, G. (2001). Biological monitoring: Lichens as bioindicators of air pollution assessment-A review. Environmental Pollution, 114, 471-492.

Davies, L., Bates, J. W., Bell, J. N. B., James, P. W., \& Purvis, O. W. (2007). Diversity and sensitivity of epiphytes to oxides of nitrogen in London. Environmental Pollution, 146, 299-310.

Dudek, K. (1974). Porosty epifityczne Skawiny. M.Sc. Thesis, Jagiellonian University, Kraków.

Fałtynowicz, W. (2003). The lichens, licheniculous and allied fungi of Poland-An annotated checklist. Biodiversity of Poland (Vol. 6). IB PAN, Kraków.

Frati, L., Caprasecca, E., Santoni, S., Gaggi, C., Guttova, A., Gaudino, S., et al. (2006). Effects of $\mathrm{NO}_{2}$ and $\mathrm{NH}_{3}$ from road traffic on epiphytic lichens. Environmental Pollution, 142, 58-64. 
German, K. (2007). Środowisko przyrodnicze Krakowa i jego wpływ na warunki klimatyczne. In D. Matuszko (Ed.), Klimat Krakowa w XX wieku. Kraków: IGiGP UJ.

Gilbert, O. L. (1968). The effect of $\mathrm{SO}_{2}$ on lichens and bryophytes around Newcastle upon Tyne. Air Pollution Proceedings of the first European Congress on the Influence of Air Pollution on Plants and Animals, (pp. 223-233). Wageningen: Pudoc.

Gilbert, O. L. (1971). The effect of airborne fluorides on lichens. Lichenologist, 5, 26-32.

Gombert, S., Asta, J., \& Seaward, M. R. D. (2004). Assessment of lichen diversity by index of atmospheric purity (IAP), index of human impact (IHI) and other environmental factors in an urban area (Grenoble, southeast France). Science of the Total Environment, 324, 183-199.

Hauck, M., Jürgens, S. R., Brinkmann, M., \& Hermingaus, S. (2008). Surface hydrophobicity causes $\mathrm{SO}_{2}$ tolerance in lichens. Annals of Botany-London, 101, 531-539.

Hawksworth, D. L. (2002). Bioindication: Calibrated scales and their utility. In P. L. Nimis, C. Scheidegger, P. A. Wolseley (Eds.) (2002). Monitoring with lichensMSonitoring lichens (pp. 11-20). Kluwer Academic Publishers.

Hawksworth, D. L., \& Rose, F. (1970). Qualitative scale for estimating sulphur dioxide air pollution in England and Wales using epiphytic lichens. Nature, 227, 145-148.

Index Fungorum (2010). http://www.indexfungorum.org. Accessed January 2010.

Isocrono, D., Matteuci, E., Ferrarese, A., Pensi, E., \& Piervittori, R. (2007). Lichen colonization in the city of Turin (N Italy) based on current and historical data. Environmental Pollution, 145, 258-265.

Kiszka, J. (1992). Lichen indication in the Przemyśl District (S.E. Poland). Ver Geobotanica, 107, 287-291.

Larsen, R. S., Bell, J. N. B., James, P. W., Chimonides, P. J., Rumsey, F. J., Tremper, A., et al. (2007). Lichen and bryophyte distribution on oak in London in relation to air pollution and bark acidity. Environmental Pollution, 146, 332-340.

Le Blanc, F., \& De Sloover, J. (1970). Relation between industrialization and the distribution and growth of epiphytic lichens and mosses in Montreal. Canadian Journal of Botany, 48, 1485-1496.

Loppi, S., \& Corsini, A. (2003). Diversity of epihytic lichens and metal contents of Parmelia caperata thalli as monitors of air pollution in the town of Pistoia (Central Italy). Environmental Monitoring and Assessment, 86, 289-301.

Loppi, S., Ivanov, D., \& Boccardi, R. (2002). Biodiversity of epiphytic lichens and air pollution in the town of Siena (Central Italy). Environmental Pollution, 116, 123-128.

Loppi, S., Frati, L., Paoli, L., Bigagli, V., Rossetti, C., Bruscoli, C., et al. (2004). Biodiversity of epiphytic lichens and heavy metal contents of Flavoparmelia caperata thalli as indicators of temporal variations of air pollution in the town of Montecatini Terme (central Italy). Science of the Total Environment, 326, 113-122.
Małopolska Sieć Monitoringu Powietrza (Air Monitoring Network in Małopolska) (2007). http://monitoring. krakow.pios.gov.pl/iseo. Accessed in 2007.

Matuszko D. (Ed.) (2007). Klimat Krakowa w XX wieku, (pp. 251). IGiGP UJ, Kraków.

Munzi, S., Ravera, S., \& Caneva, G. (2007). Epiphytic lichens as indicators of environmental quality in Rome. Environmental Pollution, 146, 350-358.

Nash, T. H. (1973). Sensitivity of lichens to sulphur dioxide. Bryologist, 76, 333-339.

Nimis, P. L., Scheidegger, C., \& Wolseley, P. A. (Eds.) (2002). Monitoring with lichens-Monitoring lichens, (p. 408). Kluwer Academic Publishers.

Nylander, W. (1866). Les Lichenes du Jardin du Luxembourg. Bulletin de la SocieÂteÂ Botanique de France, 13, 364-372.

Olech, M., \& Dudek, K. (1981). Epiphytic lichens of Skawina (Southern Poland). Zeszyty Naukowe Uniwersytetu Jagiellońskiego DLXVI. Prace Botaniczne, 8, 173-189.

Olech, M., Kajfosz, J., Szymczyk, S., \& Wodniecki, P. (1981). Fluorine content in epiphytic lichens and mosses. Zeszyty Naukowe Uniwersytetu Jagiellońskiego DLXVI. Prace Botaniczne, 8, 165-171.

Purvis, O. W., Chimonides, J., Din, V., Erotokritou, L., Jeffries, T., Jones, G. C., et al. (2003). Which factors are responsible for the changing lichen floras of London? Science of the Total Environment, 310, 179189.

Regulation by Polish Minister of the Environment from the 9th of July 2004 about legally protected wild-living species of fungi (Rozporzaçzenie Ministra Środowiska z dnia 9 lipca 2004 r. w sprawie gatunków dziko występujących grzybów objętych ochrona). Dz. U. Nr 168, poz. 1765.

Rose, F., \& Hawksworth, D. L. (1981). Lichen recolonization in London's cleaner air. Nature, 289, 289-292.

Seaward, M. R. D. (1993). Lichens and sulphur dioxide air pollution: Field studies. Environmental Review, 1, 7391.

Seaward, M. R. D. (1997). Urban deserts bloom: A lichen renaissance. Bibliotheca Lichenol, 67, 297-309.

Seaward, M. R. D., \& Coppins, B. J. (2004). Lichens and hypertrophication. Bibliotheca Lichenol, 88, 561-572.

Seaward, M. R. D., \& Letrouit-Galinou, M. A. (1991). Lichens return to the Jardin du Luxembourg after an absence of almost a century. Lichenologist, 23, 181-186.

Smith, C. W., Aptroot, A., Coppins, B. J., Fletcher, A., Gilbert, O. L., James, P. W., et al. (2009). The Lichens of Great Britain and Ireland, (p. 1046). London: British Lichen Society.

StatSoft, Inc. (2009). STATISTICA (data analysis software system), version 9.0. www.statsoft.com.

Szymczyk, S., Kajfosz, J., \& Olech, M. (1993). Badanie zanieczyszczenia fluorem otoczenia Huty Aluminium w Skawinie. Ocena stanu w latach 1976, 1983 i 1991. PAN-Oddział w Krakowie. Prace Mineralogiczne, 83, 75-78.

Śliwa, L. (2007). A revision of Lecanora dispersa complex in North America. Polish Botanical Journal, 52, 1-70. 
Świeboda, M., \& Kalemba, A. (1978). The lichen Parmelia physodes (L.) Ach. as indicator for determination of the degree of atmospheric air pollution in the area contaminated by fluorine and sulphur dioxide emission. Acta Societatis Botanicorum Poloniae, 47, 25-40.

Urząd Statystyczny w Krakowie. (2008). Rocznik Statystyczny Województwa Małopolskiego (Statistical Office in Kraków. Statistical Yearbook of the Matopolska Voivoidship). Kraków.

van Dobben, H. F., Wolterbeek, H. Th., Wamelink, G. W. W., \& ter Braak, C. J. F. (2001). Relationship between epiphytic lichens, trace elements and gaseous atmospheric pollutants. Environmental Pollution, 112, 163-169.

van Herk, C. M. (1999). Mapping of ammonia pollution with epiphytic lichens in the Netherlands. Lichenologist, 31, 9-20.

Wojewódzki Inspektorat Ochrony Środowiska w Krakowie (Voivoidship Inspectorate for Environmental Protection in Kraków) (1994-2005). Reports about the state of environment in Matopolska (former Kraków Voivoidship). Państwowa Inspekcja Ochrony Środowiska, Wojewódzki Inspektorat Ochrony Środowiska w Krakowie. Biblioteka Monitoringu Środowiska, Kraków. 